\title{
Character values in "curriculum 2013" in a typical traditional house in Batang-Batang Sumenep village as a response to socio-cultural changes
}

\author{
M.R. Gunawan* \\ Universitas Negeri Malang, Malang, Indonesia
}

\begin{abstract}
Currently, typical traditional houses in Batang-Batang Sumenep have undergone changes along with the development of technology both in terms of decorative design, layout, and home models. Therefore, problems now exist because certain traditional philosophical values are now being excluded. The method used in this research was a descriptive qualitative method. The results showed that there are five values of character education in traditional houses that can be used as alternatives to address social and cultural changes. Based on the findings of the five samples of Batang-Batang village houses, the shape of the Bangsal house and the findings of the related five main character values were observed, namely: religiousness, nationalism, independence, mutual cooperation, and integrity. These values were integrated into the curriculum. Character values in traditional houses are very useful for students as they strengthen their nation's character.
\end{abstract}

Keywords: traditional houses, change, character values

\section{INTRODUCTION}

"Curriculum 2013" is the latest curriculum that began to be applied to the new school year in 2013. This curriculum has an important role in imposing the strengthening of character education in elementary schools, middle schools, high schools and even in higher education. According to Hartono (2017) the main characteristic of curriculum 2013 are integrating attitudes and skills into one lesson. Therefore, character values are integrated into every process of learning the curriculum. To build character, this curriculum continues to develop the good characters students already have (Sayono et al. 2015). In response to this, the president of the Republic of Indonesia issued a presidential regulation (Perpres, 87 2017) for strengthening character education in article 1 , aiming to build and equip a golden generation of Indonesia in 2045 with the soul of Pancasila and the education of good character values to face change in the future.

One of the options for this in Madura island is historical heritage in the physical form of traditional houses. However, the philosophical values of traditional houses in Madura have been neglected, one of which is the character value. Character is very necessary to build the nation's generational identity, considering that the current era of young people in Indonesia, especially in Madura, is experiencing a degradation of character and morals. According to data (profiles of Indonesian children, 2019), it is known that in 2017 the number of child perpetrators of criminal acts reached 3,479, and in 2018 it reached 3,048. In addition, in 2018, in Madura, there were cases of violence against high school teachers. This can be seen in the news (CNN Indonesia 2018). There is a case of beating an art teacher by suspected students in Sampang, Madura, to death. This is a severe problem.

The researcher offers an alternative solution, namely the investigation of the character depicted in the typical traditional houses in villages in Batang-Batang Sumenep Madura. The value of

*Correspondin author: riskigunawan806@gmail.com 
character education is a valuable area for study because in the era of technology and information, technology can impact the influx of outside cultural influences. According to Kusmayadi (2017), external cultural values lead to dehumanization, namely that humans are no longer valued because they are more concerned with modern technological machines. In addition, cases of degradation of character and morals occurring among adolescents are increasingly prevalent. The purpose of this research was to explore the character of Curriculum 2013 vis-à-vis traditional houses in a typical village of Sumenep as a response to socio-cultural changes. This research is comprised of three sections: (1) an overview of traditional houses of the Batang-Batang village, (2) Curriculum 2013, which grounds character, and (3) the contents of character.

\section{METHOD}

This research employed qualitative and historical methods. According Prastowo (2012), the approach is treating the object to be studied. This research was classified as descriptive qualitative research in the form of written words. Data was collected from five traditional houses in Batang-Batang village. Traditional houses were chosen based on the criteria of houses that have not been renovated. After obtaining the data, the researchers conducted field observations to each house and conduct interviews with the community. The data obtained was analyzed using a historical approach by verification (of data source criticism, source validity) and interpretation to be used as historiography.

\section{RESULTS AND DISCUSSION}

\subsection{Description of a typical traditional house in Batang-Batang Village}

The research is located in Batang-Batang Village, Batang-Batang Sumenep District, Madura. According to the Sumenep Center for Statistics (2020), the boundary of Batang-Batang District is in the north bordering the Java Sea, south of Gapura, east of Dungkek, and west of Batu Putih. Batang-Batang village itself is divided into two, namely Batang-Batang Laok (south) and BatangBatang Daya (north). The location for data collection is in Batang-Batang Daya village (north) to be precise was in the Sedung hamlet and Jeruk Porot hamlet. Traditional houses in each area have their own uniqueness and characteristics. Traditional houses according Sumardiyanto (2019) are cultural products of the community. The social values that have been maintained and carried out by the community will be reflected in elements of traditional buildings. According to Susilo (2018), the definition of a traditional house tends to be interpreted as a "place to live" (Panggenan or Panggonan, place). The traditional houses in Batang-Batang Village are included in the type Bangsal houses that have long been occupied by residents, the characteristic of this house can be seen from the shape of the roof which tends to have horns.

Traditional house architecture is much influenced by the religion, customs, and beliefs of local communities which are also influenced by climat conditions and location (Rumiawati \& Prasetyo 2013). Traditional architecture usually refers to the form of traditional houses and residential buildings made in a community environment with certain customs (Rosyadi 2015). The climate in Madura is similar to other areas in Indonesia, which have tropical climates, because of its location in the lowlands and the dry land. These conditions also affect the style of the buildings in which people in Madura live. There are at least four forms of traditional houses in Madura seen from the shape of the roof, namely trompesan, pegun, pacenan, and Bangsal.

Traditional house in the Batang-Batang Sumenep village have the characteristics of the type of roof of the house Bangsal. According to Asmarani et al. (2016), the roof of the house is the development of the roof of joglo in Javanese architecture. The type of roof joglo adapted is joglo Lawakan and joglo Sinom. The difference that the sides and back are clipped. In Batang-Batang, everyone has the same type of house, namely the roof of Bangsal. It should be noted that the 
characteristics of the Bangsal house have a horn on the top, but those found in the Batang-Batang village in the flower area do not have horns. This means the construction of a traditional house is not too influenced by Chinese culture, considering that the traditional houses around the Sumenep palace had horns on the top.

The floor of Bangsal has an average height of $40 \mathrm{~cm}$ with forming de'ondek (terraces) with the lapped bottom having a height of $20 \mathrm{~cm}$ and top $20 \mathrm{~cm}$, while its basic form consists of square and rectangular. In general, the Bangsal houses in Batang-Batang Sumenep village only have two rooms, namely the inner and outer spaces. The outer space, known as amper, is a place to receive guests while the inner space is private, for sleeping, and storing agricultural products and other valuables. The floors in the Bangsal village of Batang-Batang house are generally original material made of clay. Subsequent developments of some parts were renovated made of plaster in the form of black cement. In general, in Madura, the use of building materials such as wood and bamboo are very dominant, and most of the wood gets special treatment such as teak wood and jackfruit wood, because of very close relationships to values, norms, and customs. The walls in the traditional houses of Batang-Batang Sumenep village use more material beto pote (white stone). White stone materials are used because beto pote are the source of the material which is abundant and until now its resources are still traded. The window type in this Bangsal house is a window with two leaves, and the door has Kupu Tarung door type.

\subsection{The character of curriculum 2013}

This curriculum is the latest curriculum to take effect in the new school year 2013. The development of the 2013 curriculum is expected to produce a productive, creative, innovative generation. According to Permendikbud No. 35 of the year 2018 on changes to Permendikbud No. 58 of the year 2014 on curriculum 2013 in Junior High School/Madrasah Tsanawiyah: "Curriculum 2013 aims to prepare Indonesians to have the ability to live as a person and citizen who believe, productive, creative, innovative, and affective and able to contribute to the lives of people, countries, countries, and civilizations of the world".

As a result, the 2013 curriculum applies character content at all levels of education. Character is very useful for the nation's next generation in the future as a booster of the nation's identity at a time when social and cultural change is rapidly moving. According to the "Guidelines for Strengthening Character Education 2017," as the foundation of curriculum 2013, the national movement of character education has begun in 2010 which has spawned a pioneer school capable of carrying out character formation contextually in accordance with the potential of the local environment. The government realizes that the National Movement for Mental Revolution that strengthens character education should be implemented by all schools in Indonesia, not just limited to target schools. In response, in 2017, the president of Republic Indonesia issued presidential regulation 87 of the year 2017 concerning strengthening character education that applies to all levels of education in Indonesia.

\subsection{Tradisonal house character value content}

The character in today's era is very much needed to form a person with a noble character. Moral degradation in Indonesian adolescents is a very serious problem because, if left uncorrected, it would be like a time bomb. Therefore, as an educator who is aware of the problem, acts immediately as the savior hero of the generation of the nation, one of which provides character-based learning. Character education is a necessity in an effort to face the various challenges of character shifting faced today (Komara 2018). Character education refers to the values of the character of the nation, contained in Permendikbud No. 20 of 2018 Article (2):

a. PPK is implemented by applying Pancasila values in character education mainly covering religious values, honest, tolerant, discipline, hardworking, creative, independent, democratic, curiosity, national spirit, love of the homeland, appreciating achievements, communicative, peace of mind, fondness for reading, environmental care, social care, and responsibility. 
b. The value as referred to in paragraph (1) is the embodiment of 5 (five) interconnected main values namely religiosity, nationalism, self-reliance, mutual cooperation, and integrity integrated in the curriculum.

To find out what values are contained in the Bangsal house in Batang-Batang Sumenep Village, researchers refer to the values of national character, found in Permendikbud Number 20 of 2018 Article (2) which has been summarized into only five values. The following is a description of the five-character values found in the traditional houses of Batang-Batang Sumenep Village.

\subsubsection{Religiousness}

There is no doubt about the religious value of the Madurese people. They believe in the power of God so that they can express it in their daily lives and one of these expressions is the traditional Madurese house design. Before making a house, the Madurese community has the habit of counting the days of goodness so that the house built becomes a blessing for the home owner, right before the construction process, they dig the foundation for planting four pedestals to support the house poles. Before installing the umpak (pedestals), a salvation is held as a form of gratitude and to ask for prayers so that those who occupy the prospective house will receive safety. According to Dalyono \& Lestariningsih (2017), religiousness is the attitude and behavior of being obedient in carrying out the teachings of the religion they adhere to, tolerant of the implementation of other religions, and living in harmony with followers of other religions.

\subsubsection{Nationalism}

As another area in Indoensia will surely tip the value of nationalism, Madura people have long been promoting the value of nationalism as a manifestation of their love of their Indonesian homeland. In 1900, Indonesia was not independent but the rehabs used to respect Buppa' (Father), Bhabhu' (Mother) Ghuru (Teacher), Rato (Leader) turned out to have a profound impact on subsequent developments. Respecting Rato means respecting the leaders/bureaucracy of the authorities, Until Indonesia is independent, whoever leads the Madurese community will always be respected. This philosophy is manifested in the physical buildings of Madurese houses, the traditional buildings on average will never face the main road because they respect the nobles who will pass on the highway.

\subsubsection{Independence}

The Madurese are very independent, resilient, and hardworking. They have the desire to migrate to get a job and guarantee a happy life. It seems that the independence of the Madurese community had long been formed when they were teenagers, and this cannot be separated from where they live. The Madurese community lives in groups with their own family members known as taniang lanjeng. Tanian lanjeng contains a group of families. The residence will face south and the kitchen and drums are in the south. The pakeban (bathroom) is outside the house, while kobhung (place of worship) is located in the west. The philosophy in the house with the tanian lanjeng system is increasingly western looking and sacred. When boys turn into teenagers, they are allowed to sleep outside in places of worship. This is because they are used to keeping families out of danger from the outside and are taught to take responsibility.

\subsubsection{Cooperation}

The spirit of gotong royong (cooperation) has been ingrained in the Madura people. They help each other work together. The process of making a house is done by means of deliberation, collecting several families to take advice regarding the person's intention to build a new house. This is in accordance with the opinion of Dewantara (2017) on mutual cooperation being a dynamic principle, even more dynamic than kinship. Cooperation describes a joint effort and mutual assistance toward a common interest. 


\subsubsection{Integrity}

The unity or integrity is seen in the system of conscience of the family who lives in one tanian lanjeng. They help each other and try to get along despite having to live in a yard with their own family. The community is also friendly and hospitable to the presence of guests from other races or cultures, and guests should be welcomed like kings. Homes are sometimes constructed for guests who have been forced to stay a long time.

\section{CONCLUSION}

This research has shown that the 2013 curriculum is based on character education and is presented as a character booster to the nation's growing generation. In response to the policy, researchers suggest the government consider the character value of the typical traditional house of a BatangBatang Sumenep Madura village. The character values obtained are the manifestation of five main values that are interrelated, namely: religiousness, nationalism, independence, mutual cooperation and integrity, which are integrated into the curriculum.

\section{REFERENCES}

Asmarani, I. K. \& Antariksa, \& Ridjal, M. A. 2016. Tipologi Elemen Arsitektur Rumah Bangsal di Desa Larangan Luar Pamekasan Madura. Jurnal Tesa Arsitektur. 14 (1), 10-22.

Badan Pusat Statistik Kabupaten Sumenep. 2020. Kecamatan Batang-Batang Dalam Angka 2020.

Dalyono, B., \& Lestariningsih, D. E. 2017. Implementasi Penguatan Pendidikan Karakter di Sekolah. Jurnal Bangun Rekaprima. 3 (2), 33-42.

Dewantara, W. A. 2017. Alangkah Hebatnya Negara Gotong Royong (Indonesia dalam Kacamata Soekarno). Yogyakarta: PT Kansius.

Dharmawan, N.S. 2014. Implementasi Pendidikan Karakter Bangsa pada Mahasiswa di Perguruan Tinggi. Paper from Pembinaan Pendidikan Karakter bagi Mahasiswa PTS, Lingkungan Kopertis Wilayah VIII Tahun 2014.

Hartono, Y. 2017. Model Pembelajaran Nilai-Nilai Karakter Bangsa di Indonesia dari Masa ke Masa. Jurnal Agastya. 7 (1), 34-48.

Kerjasama Kementrian Pemberdayaan Perempuan dan Perlindungan Anak dengan Badan Pusat Statistika. 2019. Profil Anak Indonesia. Jakarta: KPPPA.

Komara, E. 2018. Penguatan Pendidikan Karakter dan Pembelajaran Abad 21. Jurnal Sipatahoenan. 4 (1), $17-26$.

Kusmayadi, Y. 2017. Hubungan Antara Pemahaman Sejarah Nasional Indonesia dan Wawasan Kebangsaan dengan Karakter Mahasiswa (Studi pada Mahasiswa Pendidikan Sejarah FKIP Universitas Galuh Ciamis). Jurnal Agastya. 7 (2), 1-19.

Pedoman PPK. 2017. Konsep dan Pedoman Penguatan Pendidikan Karakter. Pusat Analisis dan Sinkronisasi Kebijakan Sekretariat Jendral Kementrian Pendidikan dan Kebudayaan.

Peraturan Presiden (perpres) 87 tahun 2017 mengenai penguatan Pendidikan karakter

Permendikbud Nomor 35 Tahun 2018 Tentang Perubahan atas Permendikbud Nomor 58 Tahun 2014 Tentang Kurikulum 2013.

Prastowo, A. 2012. Metode Penelitian Kualitatif dalam Perspektif Rancangan Penelitian. Yogyakarta: Ar-Ruzz Media.

Rosyadi, 2015. Trdisi Membangun Rumah dalam Kajian Kearifan Lokal (Studi Kasus pada Masyarakat Adat Kampung Dukuh). Jurnal Patanjala. 7 (3), 415-430.

Rumiawati, A., Prasetyo, YH. 2013. Identifikasi Tipologi Arsitektur Rumah Tradisional Melayu di Kabupaten Langkat dan Perubahannya. Jurnal Permukiman VIII (2): 78-88.

Sayono, J., \& Nafi'ah, U., \& Wijaya, N. D. 2015. Nilai-Nilai Pendidikan Karakter dalam Dongeng Gagak Rimang. Jurnal Sejarah dan Budaya. 9 (2), 236-256.

Sumardiyanto, B. 2019. Pengaruh Renovasi Terhadap Makna Rumah Tradisional Masyarakat Jawa, Kasus Studi: Kotagede Yogyakarta. Jurnal ARTEKS. 3 (2), 99-114.

Susilo, A. G. 2018. Model Tata Masa Bangunan Rumah Tradisional Ponorogo. Jurnal Lingkungan Binaan Indonesia. 7 (1), 60-67. 